\title{
RACISM IN 42 MOVIE DIRECTED BY BRIAN HELGELAND
}

\author{
Bejo Sutrisno ${ }^{1}$ \\ bejo@stibaiecjakarta.ac.id \\ Sekolah Tinggi Bahasa Asing IEC Jakarta \\ Yuyun Dwi Laksmiati \\ yuyun2021@gmail.com \\ Sekolah Tinggi Bahasa Asing IEC Jakarta \\ Budi Rachmawati \\ b.rachmawati@stiemp.ac.id \\ Sekolah Tinggi Ilmu Ekonomi Mulya Pratama
}

Sutrisno, B., Laksmiati, Y.D. and Rachmawati, B. (2022). Racism In 42 Movie Directed By Brian

Helgeland. Journal of English Language and literature, 7(1), 65-72. doi: 10.37110/jell.v7i1.144

Received: 02-01-2022

Accepted: 25-02-2022

Published:03-03-2022

\begin{abstract}
This Thesis is an attempt to find the racism that occurred by the man character in 42 movie. There are 3 problems of the study: (1) What are the factors causing the racism in 42 movie? (2) How to determine the racism in 42 movie by Brian Helgeland? (3) What are the effects of racism in 42 movie by Brian Helgeland?. A qualitative methods used to explain about Racism in 42 movie directed by Brian Helgeland. The data were collected from websites, references books, some articles, and the original movie. The writer watched the movie many times to get the point of story in this movie. Put the dialogues or the conversation that related with the main title in this paper to analyze the data. The results of this research indicates: first, the factor of racism are from culture and America history, second, determining racism by selecting the racism action that occurred between white and black ,the third effect of racism upon the offender and upon the victim, and the last moral message from racism action in 42 movie.
\end{abstract}

Keywords: Literature, Movie, Racism Aspect

\section{INTRODUCTION}

Racism has always been a sensitive issue over time. The belief that a certain race is better than others results unfair treatment of other races. The difference of skin color and other general appearance trigger certain race to underestimate or even bully others. Even though many countries have declared their laws against racism, racism itself still remains in some aspects of life, especially in America where all kind of people from various races and nationalities live.

${ }^{1}$ Corresponding Author
The recent Black Lives Matter protests peaked on June 6 2020, when half a million people turned out in nearly 550 places across the United States. That was a single day in more than a month of protests that still continue till several days.

This is not a first racist incident against black American, In America racism has been a concerned issue. Millions of American black people died because of the lynching from 1880s to 1960s. The day when American Parliament admitted to apologize, the Supreme Court cancelled the death 
execution for the black people, because the General Attorney, intentionally slipped away the black people from the jury of this court. From now on, the election of jury in America should considerate this factor. This is as a step so black people would fully participate in living in America.

This phenomenon proves that the incident of racism already occurred for a long time ago. Memmi in Robbert Williams (2005:116) "Racism is the generalized and final assigning of values to real or imagined differences, to the accuser's benefit and at his victim's expense, in order to justify the former's own privileges or aggression." Based on statement above it can be said the racist is an actions that underlie the belief which it is a natural things.

The topic of racism has also attracted public attention, resulting in much criticism. This topic was also raised as the main theme in films and literary novel. One of movies that lifts up racism issue as its theme is 42 , directed by Brian Helgeland. The movie tells about a black skin man living in the crisis justice on that era and his struggling to against racism. The story of Jack as a main character in 42 movie who become a first black man in white circle be able to make us aware about humanity and a right for others. Based on the consideration above, the writer wants to conduct a research with the title: Racism in 42 movie directed by Brian Helgeland.

\section{REVIEW OF LITERATURE}

The theories obtained relate to factor of racism, the effect of racism and how to determine the racism.

\section{Racism}

Racism is a word which should rejected to people who have reasonable. Racism is a belief of some people who claim the biological differences is a factor of human ability to determine their achievement. Racism itself has a meaning if their race is superior, so they feel entitled to control other race.

Racism occurs for some people who have differences from the other. The writer would collect the opinion from expert for explaining the racism itself.

According to Marable (2006:35) is typical in describing racism as "the system of ignorance, exploitation and power used to oppress African American, Latinos , Asians , Pacific Americans, native Americans and other people on the basis of ethnicity, culture, mannerism, and color." It means the racism is suppression and it depiction of ignorance.

According to Crow (2006:2) explained "blacks' social standing as the result of their biological and moral inferiority, color-blind racism avoids such facile arguments. Instead, whites rationalize minorities' contemporary status as the product of market dynamics, naturally occurring phenomena, and blacks' imputed cultural limitations." Through the definitions the white people think they are the contemporary status as the product of market dynamics and conversely with black people who standing as the result of their biological and moral inferiority.

Essed (1991:43) outlined that "Racism must be understood as ideology, structure and process in which inequalities inherent in the wider social structure are related, in a deterministic way, to biological and cultural factors attributed to those who are seen as a different 'race' or 'ethnic group"'. Based on the definition above, racism as ideology and process for the differences between structure social race which seen different from the other race.

Whereas Wetherell and Potter (1992:3) stated that we are not wanting to argue that racism is a simple matter of linguistic practice. Investigations of racism must also focus on institutional practices, on discriminatory actions and on social structures and social divisions. But the study of these things is intertwined with the study of discourse. Our emphasis will be on the ways in which a society gives voice to racism and how forms of discourse institute, solidify, change, create and reproduce social formations. 
Regarding on the definition that racism is not a simple matter, it require a serious attention. The society need to gives voice to racism and how forms of discourse institute, solidify, change, create, and reproduce social formations.

According to Memmi in Robbert Williams (2005:116) "Racism is the generalized and final assigning of values to real or imagined differences, to the accuser's benefit and at his victim's expense, in order to justify the former's own privileges or aggression." The writer assumes that racism is a favorable action because it is able to use as a reason for blaming the weaker race.

Memmi in Teresa Aguado Odina et al. (2007:47) gave more explanation that "Racism is a cultural discourse that surrounds us from infancy, it is in the air that we breathe, in our parents' advice and their ways of thinking, in cultural rites. We are exposed to it at school, in the street, and in the newspapers, and even in the works of people we are supposed to admire and who can, in fact, be admirable." Based on the definition above racism is a culture that our parents give through understanding in their advice ranging from children to adult.

In addition to Lawrence and Terry (2004), they stated "Racism is race prejudice plus power." It means racism is race prejudice plus power from the superior race to weaker race.

According to Teresa Aguado et al. (2007:19) Racism is discriminating against a person because of their color or race Not interacting with black people Fighting with someone because he or she is from another country Only valuing people from your own group Associating prejudices with a group that we call a race.

From all definitions above the writer could conclude that racism is depiction of ignorance. The differences between black and white skin which make the whites race higher that the other. Racism is serious problem which is needed attention from society for changing the conditions. Racism also a culture and an understanding that our parents taught to us and a reason for human action for do racist.

\section{Factor of Racism}

Racism occurs in many factors, the writer would like to collect some factors that causing the racism from some experts.

According to Gay (2005:159) "Those aspect of our culture and history that come most often to our attention, usually because they have been popularized by or expropriated by the dominant society, tend to line up along the side of assimilation and, as consequence, are available as vehicles for our oppression." Based on the definition above the aspect of culture and history tend to as vehicles for oppressions, usually because they have been popularized by other people, med, and their society.

According to Grover (1997:34) "Whiteness means being dominant and it stands to reason that if somebody's dominant, somebody else is down. It's delightful to be able to mindlessly enjoy "white" culture". It means that white is dominant, it has be a culture for them to enjoy their destiny because they are white.

Meanwhile, Goldberg in Keiko (2007:5) stated that "... The concept of race is socially and historically constructed in the particular context of each society. It has been utilized with other factors, such as gender and class, when a nation-state formed itself by defining who should be the authentic "nation" and who should not ...". Based on the definition above the social and historical from each society is important in every country. Gender and class is an authentic for nation, by that factor the discrepancy among society makes racist appear.

Hasbrook in Coakley (2005:9) outlined "Our social class, race and ethnicity also influence physicality. For example, several scholars point out that many Black men and some Black women, particularly those from lower social class backgrounds, to adopt a certain set of physical gestures and postures denoting toughness, control, and detachment. They suggest that such physicality is a means of responding to and coping with institutionalized racism." Regarding on the 
definition, social class, race, ethnicity and also influence physicality, are the most causes of the occurrence of racist acts, especially social class background.

Those are supported by Smadley and Smadley in Elvira Craig de Silva et al. (2007:5) that "Race as a biological fact has been invalidated by biologists and geneticists, but race as a social construct is very real. Physical traits still have meaning as markers of social race identity. It is this social race identity that confers placement in the social hierarchy of society, and thereby access to or denial of privileges, power, and wealth". The writer thinks physical traits still have meaning as markers of social race identity.

According to Pinderhughes in Elvira Craig de Silva et al. (2007:5) "The status assignment based on skin color identity has evolved into complex social structures that promote a power differential between Whites and various people-of-color". It means racism is normal ways for people in providing rights and obligation based on skin color. It is like unwritten law, if the white race is more priority than black, and is applied by white race.

Pinderhughes in Elvira Craig de Silva et al. (2007:8) also gave statement that "These powerassigning social structures in the form of institutional racism affect the life opportunities, lifestyles, and quality of life for both Whites and people-of-color. In so doing they compound, exaggerate, and distort biological and behavioral differences and reinforce misconceptions, myths, and distortions on the part of both groups about one another". Based on the definition racism affect the life opportunities, life-styles, and quality of life for both Whites and people-of-color. White people are always being a main problem about behavioral differences and reinforce misconceptions, myths and distortion on the part of both groups about one another.

When someone is racist, there are lots of people they don't like. They don't like all kinds of people. Racists don't want immigrants, they don't accept and they don't like people who come from other countries, especially if they're Asian or African or
South American countries. Because of racism, they don't want you because of the color of your skin, or because you're from another country... or because you've got a different accent (Teresa Aguado Odina, et al., 2007:18).

To sum up, racism occurs because the thinking of other people who do not like the other people who has a different country, skin color, and different accent. and racism also do not want immigrants.

According to Van Dijk in Teresa Aguado Odina et al. (2007:43) 'Racism is not a 'natural' tendency for any human group, but a social invention to hold power and maintain a privileged situation over others whose origin, appearance, or culture are different". Through the definition racism is not a natural habitual, some people make and control the power in their own privilege to make differences in culture, origin and, appearance from other race.

From all definitions above, the writer concludes that factors of racism are social class, race, ethnicity, other people who has a different country, skin color, different accents, immigrants, classifying human beings, and not interacting with black people. T1he most of racism factor is a belief of white race who always think they are superior, has a power, has a highest caste and the most feasible to take

\section{The Effect of Racism}

Racism could impacted to the victim and offender such negative or positive thing based on the action. Racism can have a lot of effects on a victim. Victims can become angry, bitter or violent. It can destroy a person's self esteem. It can destroy communities and creates divisions within society. A Cornell News Service study in 2009 did a study on the effects of racism saying that racial discrimination erodes mental health. The study finds that black people may have poorer mental health as a result of two mechanisms: Firstly; chronic exposure to racial discrimination leads to more experiences of daily discrimination and secondly it results in an accumulation of daily negative events across various domains of life, from family, friends, health 
and finances. A person's whole world can change from experiencing discrimination and they can become depressed, anxious and mentally unwell.

It means the effect of racism can make the victim and the offender felt angry, bitter and violent. It also could destroyed the communities, and make people become depressed, anxious and mentally unwell.

According to Clark et al in Jhon Crocker (2007:2) "Racism may cause one to become anxious, paranoid, angry, helpless/hopeless, frustrated, resentful, and fearful"

It means racism could gave a bad impact to the sufferer, not only physically but also on their psychologically. Racism action could make the sufferer become paranoid, hopeless, frustrated, and fearful.

Racism can result in ongoing psychological stress and anxiety, which can have an impact on work, family life and overall health and well being

Racism can prevent people from having equal opportunities to better their lives and is primary reason for higher levels of unemployment and under employment among original people and other racialized groups

Racism can prevent groups and communities from interacting with each other and can increase discomfort, fear and resentment. Racism can have negative effect on an individual's physical and mental health. It can be concluded that there are 6 bad impacts to the sufferer, there are : prevent members of certain groups, feels isolate, stress and anxiety, prevent the opportunities to better lives, prevent to interacting with each other, and mental health

\section{METHOD}

The research design of this study is a content analysis with qualitative approach. Moleong (2009:56) stated that qualitative method is a research procedure that obtains descriptive data in written or spoken form from the people and their behavior which is being observed. While Kasiram
(2010:4) outlined that research is an activity which aims to get the truth about a problem through scientific method.

\section{FINDING AND DISCUSSION}

\section{The Factors Causing the Racism in 42 Movie}

Racism had been in America since Africans came to America for having new lives. Americans did not want immigrants in their society. It was the main factor that caused the racism in America in around 1945. In this movie, the writer found supporting dialogues of factors causing the racism as a first scene from the narrator.

Supporting dialogues I.

Narrator : Life in the United States could return to normal. They returned home from fighting to free the world from tyranny .. only to find racism, segregation and Jim Crow law still waiting at home. Segregation was the law and no group was more scrupulous in its observance of custom than organized baseball. There was a long road ahead. If African Americans dreamed of playing baseball, it was not for the Yankees.

On Durations: 00.00.50

In American history, black people were like enemies for white people. Jim Crow's law made every person in America obey the rules aiming the blacks to always be on a lower rank and not in a priority. That factor was explained by the narrator as a first factor causing the racism in 42 movie. The writer also found another supporting dialogue that consists of the factors causing the racism as below.

Hig :I mean, I can't believe it. I speak my mind, and they trade me. This ain't the America I know. Uh-uh. Home of the free, land of the brave? You hear me?

Where they sending you, Hig?

Hig :Pittsburgh. For cash and some Italian outfielder, named Gionfriddo. Pittsburgh. I mean... 
The scene tells about one of Jackie's teammate named Hig, was transferred to other team, Pittsburgh. His petition that he made with his friends in order to refuse to be in a team with Jackie is rejected. In his dialogue he said, "This ain't the America I know". It meant American people in that era still adopted Jim Crow's law. They believed that it was degradation for them if the blacks priority more reverence than the whites. Supporter :We don't want you here!

Hey! Hey, Nigger boy!

Get the hell out of Cincinnati!

We don't want you here!

Go back to Brooklyn!

You the batboy, sambo?

Hey, nigger! I'm talking to you!

Get the hell out of Cincinnati!

We don't want you here, boy!

Kid :Nigger!

As Memmi (2007:47) explained, the racism could adopt from the culture that our parents gave. It shows on this scene, when white supporters in Cincinnati who hated black people shouted out an insult for Jackie when he appeared in the field, all parents and old men did not stop yelling to Jackie. A kid observed the situation what the whites did to the blacks. First, he felt uncomfortable and confused about the situation, but it made him feels like left behind and not a part of the whites. Finally he did what the previous whites did, he also yelled to Jackie, "Nigger!" and that was kind of a factor of racism. The culture which made the differences between black and white was adopted from parents to their children.

\section{Determining the Racism}

Racism can be denoted by yelling, say one word that kills others' heart, sarcastic gaze, and the most known was by action. Action from one person to others that consist of sarcasm is racism, with the size of body, color skin, dialect, race, and caste in society. In 42 movie, the racism are focused on black people who try to survive on their place for living into a better life.

Rickey :I know you can hit behind the runner. That you can read a pitch. One question is can you control your temper?

Jackie :My temper?

Rickey: Yes, your temper! What are you, deaf ?A black man in white baseball, heh, can you imagine the reaction? The vitriol? Dodgers check into a hotel, a, uh, a decent, good hotel. You're worn out from the road. Some clerk won't give you the pen to sign in with. "We got no room for you, boy. Not even down in the coal bin where you belong."

This was the first time for Jackie to hear directly insults for himself. He did not know anything what the purpose on Rickey's words. Rickey tested Jackie's tempers and waited his reaction. Rickey explained the risk for joining the big club, especially white club.

Rickey's saying then proved on scene 01.32.59 durations, when Philadelphia club were going to do anything to cancel the blacks to come to Philadelphia town. Herbs tried to block Brooklyn ways to the match area. They canceled Brooklyn Dodger's hotel reservations and made them displaced on the road.

\section{The Effect of Racism}

Racism never gives advantages for anyone, neither the whites nor the blacks. Almost all racism are committed by whites, because they have a power to control anything, but world is changing, people try to improve their level in society. As much as racist do by whites, the more other whites try to maintain their pride to make a good impressions although behind it all, everything is just affectations. The writer assume racism could be impacted on offenders and victims, the writer would like to categorize the scene into two type based on 42 movie.

\section{1) Upon the Offender}


All whites did a justification as for guilt over impairing himself and Jackie. Like it or not, white had to do it. The writer found some fact that shows the effect of racism upon the offender.

Harold :Excuse me. Hi. Jackie. Uh, Wendell, um. A request came in. Uh, Ben Chapman, he's the, uh, manager for the Phillies. You knew that. Uh, he'd like his photo taken with you.

Jackie :You been drinking, Harold?

Harold :No. No. I wish. No, Mr. Rickey, uh, he thinks it's a good idea. He says it's gonna be in every sports page across the country. An example that even the most hardened man can change.

Jackie :Chapman hasn't changed. He's just trying to save face.

Harold :Mr. Rickey says it doesn't matter if he's changed. As long as it looks like he's changed.

Wandell :Jackie, you've seen the questions come in slow. Now, just see this photo come in even slower.

Harold :Chapman said he'd come down here. Or, uh, he could meet you in the runway.

Jackie :No. On the field. Where everyone can see.

Jackie who got the discrimination for himself had a chance to reject the offer, but Jackie did not do that. He replayed his humiliations in intelligent ways. He brought Chapman into the middle of the field and made all reporters and whites supporters see what happened. He made the whites ask for apologize to him, and made his feeling below his caste, but all what Chapman did was a pretend for keeping his position as a coach, but on that time, Chapman lost.

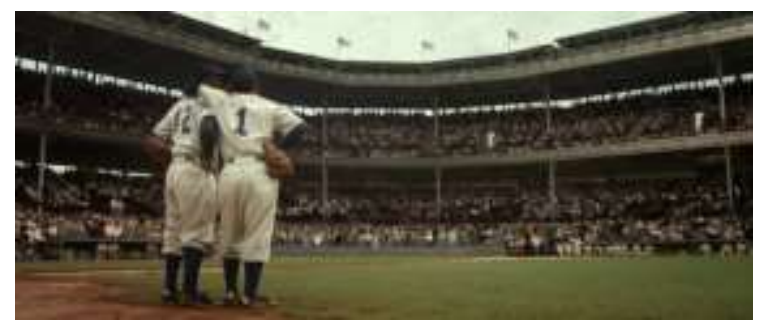

Fig.1: Pee Wee and Jackie on the field

From this scene, Pee Wee made all whites think. He made all white parents and old men felt ashamed of their actions in front their children. Pee Wee did it for showing the humanity for his children. $\mathrm{He}$ knew if what he had done all this time was wrong, he had to be apart to clarify there were no caste between the blacks and the whites. He wanted to change all citizens of Cincinnati's mindset to receive the blacks as a human, not a crum.

\section{2) Upon the Victims}

The racism that happened made Jackie suffered, oppressed, and blamed himself for what happened into his family. The writer found three scenes that prove the effects of racism upon the victim, especially to Jackie as a black main character.

Jackie :No! No. The next white son of a bitch that opens his mouth... .I'll smash his goddamn teeth in.

Rickey :You can't do that, Jack.

Jackie :I'm supposed to just let this go on?

Rickey :These men have to live with themselves.

Jackie :I have to live with myself too. Right now I'm living a sermon out there.

Rickey :You don't matter now, Jack. You're in this thing. You don't have the right to pull out from the backing of people... ...that believe in you, that respect you, that need you.

Jackie felt distressful, He suffered from the insults that he got in the face of common, moreover his wife had to get that insult too, but he could not do anything. This is the peak where Jackie regretted his promises he made before, to not do any retaliate or make a defense on him. Blacks and whites saw what happened in the field. Racism happened, but Jackie had to survive, even his wife who saw it only felt the sorrow in her heart.

\section{CONCLUSION}


After the writer analyzes movie 42 about racism between black and white races, the writer gets conclusion that racism about race occurred in America for long time ago. Based on this movie, racism occurred to main character as a black, Jackie. Racism occurred because the whites never allowed they race be generalized with black race. Whites always push their ways for casting out Jackie who starting his game in new club Brooklyn Dodgers. This is the first time in America, black joined into white baseball club. The writer was found three factors that causing the racism in 42 movie, first; when the narrator told about American histories, second; when Jackie's teammates grumbling, and finally; when kid whites shouting Jackie.

The writer determined some dialogues and pictures were supported as categories of racism by analyzing and relating the scenes from experts as sources. There are eleven racism actions was founded, but the writer only input nine scenes that proved racism occurred in this movie. Some hurdles were occurred to Jackie, start from himself up to his family, such as threatening letters, humiliation, and physical actions it's all upon to Jackie as a black America from whites were kinds of racism.

After watching 42 movie repeatedly, the writer could decide the effect of racism, first upon the offender, and second upon the victims. There are two supporting dialogues and pictures were founded as effect upon the offender; first when chapman asked an apology from Jackie, and second when Pee Wee and Jackie stand on the field together. There also three supporting dialogues and pictures were founded as effect upon the victim; first, when Jackie excite his emotions in the middle of games, second; when Jackie fell on the field and nobody helped, and finally; when Rickey told the fact about Jackie's letters to Pee Wee.

\section{REFERENCES}

Allred, M. \& G. (2020). Representing Employees Who Have Experienced Race, Religious or National Origin Discrimination. https://www.amglaw.com/Employment-
Law/Race-Religious-National-Origin-

Discrimination.shtml

Andrews. (1998). Supreme Court of British Columbia. Vancouver: Law Society of British Columbia.

Araki, K. (2007). Building a New Racial World Order: Intersection of Pan-Asianism and PanAfricanism in the Post-WWI World. G-SEC WORKING PAPER No.15.

Bonilla, Eduardo., S. (2006). Color Blind Racism and the Persistence of Racial Inequality in the Unitetd States. United States of America. Rowman \& littlefield publisher, Inc.

Coakley, J. and P. (2005). Inside Sports. USA and Canada. Routledge.

Crocker, J. (2007). THE EFFECTS OF RACISMRELATED STRESS ON THE PSYCHOLOGICAL AND PHYSIOLOGICAL WELL-BEING OF NON-WHITES. River Academic Journal.

Gins, R. (2005). Popular Cultur: A READER. London. SAGE Publications Ltd.

Marable, M. (2006). Caste Wars a Philosophy of Discrimination. New York. Routledge.

Miles, R. (1998). Racism. Oxford University Press.

Milkovich, G. (2001). Forms of Discrimination. New York: Harper Collins Publisher.

Palmer, E. (1990). Everything You Need to Know About Discrimination. New York: The Rosem Publishing Group, INC.

Pelinka, Anton., Bischof, Karin., and Stogner, K. (2010). Handbook of prejudice. Cambria press.

Racism Free Edmonton ACTION PLAN. (n.d.). https://www.auma.ca/sites/default/files/sample_ action_plans_-_edmonton.pdf

RACISM is so yesterday. (2020). https://catholicismandracism.weebly.com/cause s-and-effects-of-racism.html

Reisigl, Martin., and wodak, R. (2005). Discourse and discrimination: Rhetorics of Racism and Antisemitism. New York. Taylor and Francis eLibrary.

Silva, E. C. de. (2007). Institutional Racism \& The Social Work Profession : A CALL TO ACTION. Washington,DC.

Williams, R. A. (2005). like a Loaded Weapon. acid-free paper. 